\title{
HUBUNGAN PENGETAHUAN KELAHIRAN IBU DENGAN KEJADIAN SECTIO CAESAREA PADA IBU BERSALIN DI BANGSAL KEBIDANAN RSU MAIJAND H.A THALIB
}

\author{
Emitra Fatriona \\ Akademi Keperawatan Bina Insani Sakti \\ Email Korespondensi: fatrionanaila@gmail.com \\ Disubmit: 24 Januari 2022 Diterima: 27 Januari 2022 Diterbitkan: 02 Februari 2022 \\ DOI: https://doi.org/10.33024/mnj.v5i2.5918
}

\section{ABSTRACT: CORRELATION OF GIVING BIRTH MOTHER KNOWLEDGE AND THE CASE OF CAESARIAN BIRTH IN OBSTETRIC WARD OF RSU MAIJAND H.A DISTRICT HOSPITAL IN SUNGAI PENUH IN 2021.}

Background: Caesarian birth is designated for special medical indication, either from the mom or from the fetus. Caesarian birth should be considered as an alternative only when the normal birth can't be followed due to some medical indication. Although $90 \%$ of birth process are classified as normal birth without complication, but when the complication happened the medical treatment taken should prioritize the health of mom and fetus. Caesarian birth should be treated as the last option of giving birth when normal birth can't be done due to some medical indication.

Purpose: This research is being conducted with the purpose of exploring the correlation of mom's knowledge and the case of caesarian birth in obstetric ward of RSU Mayjend H.a talib district hospital Kerinci in 2021.

Research Methoads: This research is an analytical descriptive with cross sectional study in obstetic ward of Rsu. mayjend District Hospital in Sungai Penuh with 30 respondents, using questionnaire and medical record in obstetric ward, and it found that 24 of them (80\%) are having caesarian birth, while 6 respondents (20\%) are having normal birth. It starts with editing, coding, data entry, tabulating and cleaning, then being analyzed with uni-variat and bi-variat using chi square test.

Results: Coming from the result of this research, we found that $80 \%$ of the data are having caesarian birth, and 63.3\% of them are driven by lack of knowledge of the mom. the moms are having record/history with caesarian in the previous birth, $6,7 \%$ are There is a relationship between knowledge and sectio caesarea of Rsu. Mayjend h.A thalib district hospital in Sungai Penuh in 2021. Statistic test result using chi-square shows that $p=0,0032(p<0.05)$.

Conclusion: Therefore, it's being suggested to medical staff and nurses to provide an education to moms regarding normal birth and its pathologies during ANC, in order to be mom's consideration on choosing the correct way of giving birth.

Keywords: Case of caesarian, knowledge 


\section{INTISARI: HUBUNGAN PENGETAHUAN KELAHIRAN IBU DENGAN KEJADIAN SECTIO CAESAREA PADA IBU BERSALIN DI BANGSAL KEBIDANAN RSU MAYJEND H.A THALIB SUNGAI PENUH TAHUN 2021}

Latar Belakang: Persalinan dengan Sectio Caesarea ditujukan untuk indikasi medis tertentu, baik dari faktor ibu maupun faktor janin. Seharusnya Sectio Caesarea dipahami sebagai alternatif persalinan ketika persalinan normal tidak bisa dilakukan. Meski $90 \%$ persalinan dikategorikan persalinan normal tanpa komplikasi, namun apabila terjadi komplikasi maka penanganan selalu berpegang teguh ada kesehatan ibu dan janin. Tindakan Sectio Caesarea merupakan pilihan persalinan terakhir setelah persalinan pervaginam tidak layak dilakukan.

Tujuan: Tujuan Penelitian untuk mengetahui Hubungan pengetahuan dengan kejadian sectio caesrea pada ibu bersalin di bangsal kebidanan RSU Mayjend H.A Thalib Sungai Penuh Tahun 2021.

Metode Penelitian: Penelitian ini merupakan penelitian deskriftif analitik dengan cross sectional study yang dilakukan di bangsal Kebidanan RSU. Mayjend H.A Thalib sebanyak 30 responden, yang bersalin dengan sebanyak $24(80,0 \%)$ responden dan 6 (20,0\%) responden bersalin dengan normal, pada saat penelitian dengan menngunakan kuisioner ddan rekam medik bangsal kebidanan. Di mulai dengan editing, coding, entry, tabulating, dan cleaning kemudian di analisa secara univariat dan bivariat dengan uji chissquare.

Hasil: Berdasarkan hasil penelitian $(80,0 \%)$ bersalin dengan Sectio Caesarea,lebih dari separoh $(63,3 \%)$ pengetahuan kurang baik. Terdapat hubungan antara pengetahuan dengan sectio caesarea di RSU Mayjend H.A Thalib Sungai Penuh tahun 2021, hasil uji statistic menggunakan chi- square di dapatkan nilai $p=0,032(p<0,05)$.

Kesimpulan: Oleh sebab itu di sarankan pada petugas medis dan perawat untuk memberikan penyuluhan kesehatan tentang pengetahuan persalinan normal dan patologis pada saat ANC, sehingga bisa menjadi pertimbangan pada saat melakukan persalinan dengan cara yang tepat.

Kata Kunci : Kejadian Sectio caesarea dan Pengetahuan 


\section{PENDAHULUAN}

Persalinan merupakan tahap akhir dari proses kehamilan, oleh karena itu banyak wanita yang akan bersalin merasa cemas dan gelisah menanti saat kelahiran. Setiap wanita menginginkan persalinan yang lancar dan dapat melahirkan bayinya dengan sempurna seperti kita ketahui ada cara persalinan pervagianam yang lebih dikenal sebagai persalinan normal atau alami. Sedangan cara bersalin dengan cara pembedahan disebut dengan Sectio Caesarea, yaitu seuatu persalian buatan dimana janin dilahirkan melalui suatu insisi pada dinding perut dan rahim dengan sayatan rahim dalam keadaan utuh serta berat badan janin diatas 500 gram (sarwono, 2009).

Beberapa tahun yang lalu melahirkan dengan Sectio Caesarea menjadi hal yang menakutkan. Karena itu pembedahan dilakukan apabila persalinan normal akan membahayakan ibu dan janin. Seiring berjalannya waktu serta berkembangnya teknologi dibidang kedokteran pandangan tersebut mulai bergeser, kini Sectio Caesarea kadang menjadi alternetif persalinan yang mudah dan nyaman, anggapan ini membuat ibu-ibu memilih bersalin secara Sectio Caesarea dari pada persalinan alamiah atau persalinan normal (Kasdu, 2003).

Angka kejadian Sectio Caesarea menurut survey Nasional pada tahun 2018 di Indonesia adalah 921.000 angka kejadian Sectio dari 4.039.000 persalinan atau sekitar 22,8\% dari seluruh angka persalinan. Pada tahun 2016 angka kejadian Sectio Caesarea mengalami peningkatan menjadi $28,7 \%$ dari seluruh persalian. Sedangkan pada tahun 2013 mengalami sedikit menurun menjadi
28\% yang melakukan Sectio Caesarea dari seluruh persalian. Sedangkan pada tahun 2014 angka kejadian Sectio Caesarea terus meningkat menjadi 29,3\%, pada tahun 2015 juga mengalami peningkatan sebesar 31,9\% dari seluruh angka persalinan (Dinkes, 2015). Angka kejadian Sectio Caesarea di Profinsi jambi Tahun 2015 sebanyak 3.041 dari 170.000 persalinan atau sekitar $20 \%$ dari seluruh persalinan, mengalami peningkatan 25,6\% pada tahun 2018 (Dinkes Provinsi Sumatera, 2018).

Pada tahun 2017-2018, persalinan secara Sectio Caesarea terus meningkat, faktor terjadinya Sectio Caesarea bisa di sebabkan oleh faktor ibu dan faktor janin. Dari data persalinan yang di dapatkan kejadian persalinan secara Sectio Caesarea akan terus meningkat dalam kurun waktu 10 tahun mendatang yaitu mencapai 27\% dari seluruh kejadian persalinan (Profile Dinkes, 2018).

Berdasarkan data Dinas Kesehatan Kota Jambi 2018, Kasus kematian Ibu pada tahun 2015 bejumlah 15 kasus, turun jika dibanding tahun 2017, yaitu sebanyak 16 orang. Adapun rincian kematian ibu ini terdiri dari kematian ibu hamil 4 orang, kematian ibu bersalin 5 orang dan kematian ibu nifas 6 orang. Sementara jika dilihat berdasarkan umur, kurang dari 20 tahun tidak ada, $20 \mathrm{~s} / \mathrm{d} 34$ tahun sebanyak 11 orang dan diatas 34 tahun 4 orang. (Profil Dinas Kesehatan Kota, 2018).

Pada tahun-tahun terakhir, kelahiran Caesar meningkat tajam, sebagian besar karena meluasnya pengenalan gawat janin yang jelas maupun yang masih merupakan dugaan, yang makin dapat dipertegas. Bahwa operasi caesar jauh lebih aman dari pada dahulu. Hal ini karena 
adanya antibiotika, transfusi darah, teknik operasi yang lebih sempurna dan anastesia yang lebih baik, sehingga frekwensi persalinan caesar di negara-negara maju berkisar antara 1,5 dan $7 \%$ dari semua persalinan (Mitayani, 2009).

Persalinan dengan Sectio Caesarea ditujukan untuk indikasi medis tertentu, baik dari faktor ibu maupun faktor janin. Seharusnya Sectio Caesarea dipahami sebagai alternatif persalinan ketika persalinan normal tidak bisa dilakukan. Meski $90 \%$ persalinan dikategorikan persalinan normal tanpa komplikasi, namun apabila terjadi komplikasi maka penanganan selalu berpegang teguh ada kesehatan ibu dan janin. Tindakan Sectio Caesarea merupakan pilihan persalianan terakhir setelah persalian pervaginam tidak layak dilakukan (Maryam, 2009).

Banyak faktor yang melatar belakangi terjadinya Sectio Caesarea terutama faktor patologis, misalnya persalinan lama, Placenta Previa, Panggul Sempit, Ketuban Pecah Dini, Kelainan Letak Janin, Gawat Janin, Anak Besar, dan masih banyak komplikasi lain yang menyebabkan terjadinya tindakan Sectio Caesarea dalam rangka menyelamatkan ibu dan janin (Sarwono, 2009).

Pengetahuan merupakan faktor yang berpengaruh terhadap keputusan seseorang yang memiliki pengetahuan yang baik tentang suatu hal, maka seseorang akan cenderung mengambil keputusan yang lebih tepat berkaitan dengan masalah tersebut, dibandingkan dengan mereka yang berepengetahuan rendah. Pengetahuan merupakan hasil tahu dan terjadi setelah orang melakukan penginderaan terhadap suatu obyek tertentu. Penginderaan terjadi melalui pancaindera manusia yakni: indra penglihatan, pendengaran, penciuman, rasa dan raba (Notoatmodjo,2010). Penelitian ini ditunjang dari beberapa penelitian yang terdahulu, sebagai perbandingan dalam melakukan penelitian. Berikut ini beberapa perbandingan pedoman dalam melakukan penelitian (Notoatmodjo, 2010).

Yulia Puspita Sari (2011), telah melakukan penelitian sebelumnya di Puskesmas Krian Sidoarjo Jawa Timur, dengan hasil penelitian yaitu Hubungan Antara Tingkat Pengetahuan Persepsi Tentang Sectio Caesarea yang disebabkan oleh $104 \mathrm{ibu}$ dengan persentase $(53,8 \%)$ berpengetahuan kurang tentang Sectio Caesarea.

Menurut Bensons dan Pernolls Cit. Adjie (2005), angka kematian karena Sectio Caesarea adalah 40-80 setiap 100.000 kelahiran angaka ini menunjukkan resiko 25 kali lebih besar dari persalinan normal. Komplikasi tindakan anestesi 10\% dari angka kematian ibu, sedangkan untuk kasus infeksi 80 kali lebih tinggi dari persalinan normal.

Adanya fenomena saat ini bahwa persalinan Sectio Caesarea dianggap lebih peraktis perlu diluruskan salah satu faktor non medis yang mempengaruhi adalah pengetahuan dan kurangnya informasi Sectio Caesarea beserta resikonya. Untuk meningkatkan pengetahuan pada masyarakat pada umumnya dan calon ibu dapat dilakukan penyuluhuan pada kaum muda misalnya, pembinaan kesehatan reproduksi pada siswa SLTA dan untuk ibu-ibu yang akan bersalin dengan memberikan pengertian sedikit demi sedikit tentang persalinan normal dan Sectio Caesarea saat antenatalkare menanamkan keyakinan bahwa persalinan normal adalah anugrah 
terindah dengan segala keunikan yang dilakukan saat itu (Yulia Puspita Sari,2011).

Berdasarkan data RSU Mayjend H.A Thalib Sungai Penuh yang peneliti dapatkan diambil 3 tahun terakhir yaitu pada tahun 2020 jumlah ibu bersalin yaitu 700 , persalinan spontan sebanyak $373(53,29 \%)$ orang dan Sectio Caesarea sebanyak 323 $(46,14 \%)$ dan vacum sebanyak 4 orang $(0,57 \%)$. Pada tahun 2019 , dari 425 persalinan terdapat $201 \quad(47,29 \%)$ persalinan spontan, 222 (52, 24\%) kasus Sectio Caesarea dan vacum $2(0,47 \%)$ orang. Sedangkan pada tahun

METODE PENELITIAN.

Jenis penelitian ini bersifat analitik dengan pendekatan cross sectional study, yaitu variabel bebas dan terikat diukur pada saat yang sama, pada waktu penelitian berlangsung dimana hasilnya dapat memberikan gambaran tentang hubungan antara dua variabel penelitian tersebut (Notoadmodjo, 2012).

Variabel independent dalam penelitian ini adalah pengetahuan ibu, sedangkan variable dependen adalah kejadian sectio caesarea di RSU mayjend H.A Thalib Sungai Penuh Tahun 2021.

Populasi adalah seluruh objek penelitian (Notoatmodjo, 2010). Populasi dari penelitian ini adalah keseluruhan pasien yang melakukan persalinan di RSU Mayjend H.A Thalib sebanyak 96 orang.

Sampel adalah objek yang diteliti dan dianggap mewakili seluruh populasi (Notoatmodjo, 2010). Sampel dalam penelitian ini adalah pasien yang mewakili populasi yang melakukan persalinan dengan bersalin di Bangsal Kebidanan RSU Mayjend H.A
2018 jumlah ibu bersalin dengan Sectio Caesarea meningkat menjadi 230 kasus (59,9\%), $154 \quad(40,10 \%)$ persalinan spontan dari 384 kasus ibu bersalin di bangsal kebidanan RSUD dr. Rasidin Padang (MR, RSU Mayjend H.A Thalib 2021).

Pada survey awal yang peneliti lakukan dengan wanwancara pada 10 (sepuluh) ibu mengatakan bahwa Sectio Caesarea bukan lagi hal yang menakutkan dikarenakan adanya kemajuan teknologi di bidang kedokteran yang membuat Sectio Caesarea menjadi lebih aman dan nyaman.

Thalib yang didapatkan sebanyak 30 orang.

Pengambilan sampel dilakukan dengan cara accidental sampling. Accidental sampling adalah pengambilan sampel secara kebetulan ditempat penelitian saat itu dan sesuai dengan kriteria yang dibutuhkan (Notoadmojo, 2008).

Adapun etika penelitian menurut Hidayat (2011), dimana etika penelitian yang harus diperhatikan adalah sebagai berikut: Informed Consent kepada responden yang diteliti, peneliti menjelaskan maksud dari penelitian serta dampak yang mungkin terjadi selama dan setelah pengumpulan data. Anonymity Untuk menjaga kerahasiaan subjek maka dalam lembar pengumpulan data peneliti tidak mencantumkan nama tapi dibei kode, dan hanya diketahui oleh peneliti. Confidentiality Peneliti menjamin kerahasiaan informasi yang diperoleh dari responden. Semua informasi yang telah dikumpulkan dijamin kerahasiaannya oleh peneliti, hanya kelompok data tertentu yang akan dilaporkan dalam riset, dan data 
yang sudah tidak digunakan lagi akan dimusnahkan.

peneliti $\begin{gathered}\text { Teknik pengumpulan data } \\ \text { peroleh dengan }\end{gathered}$ mengumpulkan data primer dan data sekunder: dengan menggunakan kuesioner, informed consent dan wawancara. Kuesioner merupakan sejumlah pertanyaan tertulis yang digunakan untuk memperoleh informasi dari responden. Kuesioner yang digunakan adalah pertanyaan terstruktur untuk mengambil data tentang sectio caesarea. Data sekunder didapatkan berdasarkan sumber data laporan harian, bulanan dan tahunan bangsal kebidanan RSU Mayjend H.A Thalib. Data yang diperoleh dari Rekam Medik RSU Mayjend H.A Thalib berupa data-data persalinan di RSU Maijand H.A Thalib Kerinci Tahun 2021.

Pengolahan data pada penelitian ini mulai dengan (Editing) pengecekan dan perbaikan isian kuisioner dilanjutkan dengan pemberian code setelah semua data diedit atau disunting, selanjutnya dilakukan pengkodean atau coding, yakni mengubah data berbentuk kalimat atau huruf menjadi data angka atau bilangan. Selanjutnya dengan penskoringan dimana peneliti memberi skor untuk masing masing pertanyaan dan selanjutnya memasukkan data yang sudah dilakukan pengkodean kedalam program komputer SPSS dan dilanjutkan Tabulating atau Memasukkan data dari hasil penelitian ke dalam tabel-tabel sesuai kriteria dan terkahir di cleaning. kegiatan pengecekan kembali untuk melihat kemungkinan-kemungkinan adanya kesalahan-kesalahan kode, kemudian dilakukan pembentulan atau koreksi.

Teknik analisa data dalam penelitian ini dengan menggunakan Analisa univariat yang dilakukan secara deskriptif atau melihat gambaran distribusi frekuensi masingmasing variabel yaitu pengetahuan ibu dan kejadian Sectio Caesarea dan analisa bivariat untuk menguji hipotesa apakah ada Hubungan pengetahuan ibu dan kejadian Sectio Caesarea di RSU Mayjend H.A Thalib Kerinci tahun 2021. Tujuan analisa bivariat ini adalah untuk melihat hubungan variabel dependen dan idependen dengan menggunakan uji chi-square pada pengolahan data dengan program SPSS, dengan derajat kepercayaan 95\% $(a=0,05)$. dengan hasil analisa penelitian ini menunjukan hubungan yang bermakna dimana nilai $p$ value $<0,032$. 


\section{HASILPENELITIAN DAN PEMBAHASAN}

Analisis Univariat

Tabel 1. Distribusi frekuensi kejadian sectio caesarea dan pengetahuan pada responden yang menjalani persalinan di bangsal kebidanan RSU Mayjend H.A Thalib.

\begin{tabular}{ccc}
\hline Kejadian Sectio Caesarea & Frekuensi & Persentase $\%$ \\
\hline Sectio caesarea & 24 & 80 \\
\hline Tidak sectio caesarea & 6 & 20 \\
\hline Total & 30 & 100,0 \\
\hline \hline Pengetahuan & Frekuensi & Persentase $\%$ \\
\hline Kurang Baik & 19 & 63,3 \\
\hline Baik & 11 & 36,7 \\
\hline Total & 30 & 100,0 \\
\hline
\end{tabular}

Berdasarkan Tabel, diketahui bahwa dari 30 responden terdapat sebagian besar responden yaitu 24 responden $(80 \%)$ malakukan sectio caesarea dan 6 responden (20\%) tidak sectio caesarea di RSU Mayjend H.A Thalib Sungai Penuh Tahun 2021.
Berdasarkan Tabel diketahui bahwa dari 30 responden sebagian besar yaitu 19 responden (63,3\%) pengetahuan kurang baik dan 11 responden $(36,7 \%)$ pengetahuan baik di RSU Mayjend H.A Thalib Sungai Penuh Tahun 2021.

Analisa Bivariat

Tabel 2. Hubungan faktor pengetahuan dengan kejadian sectio caesarea di Bangsal Kebidanan RSU Mayjend H.A Thalib Sungai Penuh.

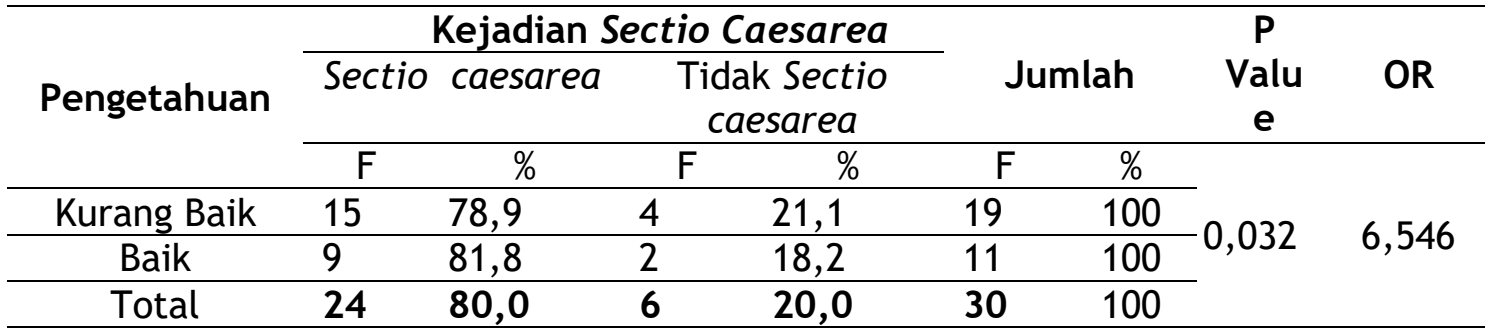

Berdasarkan tabel diketahui bahwa responden dengan pengetahuan tidak baik yang melakukan Sectio caesarea yaitu 15 responden $(78,9 \%)$ dibandingkan dengan pengetahuan tidak baik yang tidak sectio caesarea kebiasaan yaitu 4 responden $(21,1 \%)$.
Sedangkan yang memiliki pengetahuan baik dengan Sectio caesarea yaitu 9 responden $(81,8 \%)$ dibandingkan dengan pengetahuan baik dengan tidak Sectio caesarea yaitu 2 responden $(18,2 \%)$. Berdasarkan hasil analisis statistik dengan uji chi square 
diperoleh $\mathrm{p}$ value 0,032 dengan derajat kemaknaan $95 \%(\propto=0,05)$. Hal ini dapat disimpulkan bahwa ada Hubungan faktor pengetahuan dengan kejadian sectio caesarea di Bangsal Kebidanan RSU Mayjend H.A Thalib Sungai Penuh Tahun 2021. Kemudian diperoleh nilai Odds Ratio $=6,546$. artinya pengetahuan mempunyai Sehingga ibu harus diberikan penyuluhan yang baik tentang pengetahuan terhadap sectio caesarea.

PEMBAHASAN.

Hubungan Pengetahuan dengan Kejadian Sectio Caesarea pada Responden di Bangsal Kebidanan RSU Mayjend H.A Thalib Sungai Penuh Tahun 2021

Berdasarkan tabel hasil penelitian terdapat 30 orang responden yang bersalin, lebih dari separoh (80\%) diantaranya bersalin dengan cara sectio caesarea di RSU Mayjend H.A Thalib Sungai Penuh Tahun 2021. Penelitian yang dilakukan oleh Daniyah (2011) dengan judul Faktor- faktor patologis yang berhubungan dengan kejadian sectio caesarea di RSUD Solo mengatakan bahwa kejadian sectio caesarea terus meningkat pada ibu bersalin dengan faktor-faktor patologis yaitu sebesar $52 \%$. Sehingga faktor-faktor patologis seperti lilitan tali pusat, solusio placenta mempengaruhi untuk kejadian sectio caesarea. Sejalan dengan penelitian yang dilakukan oleh Misfatul (2012) dengan judul factor factor yang mempengaruhi sectio caesarea di RSU majalengka mengatakan bahwa kejadian sectio caesarea terus meningkat dari tahu ke tahun yaitu sebesar $59 \%$.
Section Caesarea adalah suatu persalinan buatan, dimana janin dilahirkan melalui suatu insisi pada dinding perut dan dinding rahim dengan syarat rahim dalam keadaan utuh serta berat janin diatas 500 gram (Wiknyosastro, 2005). Sectio Caesaria adalah suatu cara melahirkan janin dengan sayatan pada dinding uterus melalui dinding depan perut (Syaifuddin, 2002).

Analisa peneliti didapatkan bahwa kejadian sectio caesarea terus meningkat dari tahun ketahun, pada saat ini persalinan secara sectio caesarea bukan lagi menjadi hal yang menakutkan karena responden berasumsi bahwa dengan kemajuan teknologi dibidang kedokteran resiko sectio caesarea semakin berkurang dan dari segi pembiayaan sectio caesarea dengan indikasi medis di biayai oleh asuransi kesehatan. Hal ini membuat responden dapat memutuskan persalinan sectio caesarea dengan mudah. Pada penelitian ini dari 30 responden 6 responden bersalin secara normal sedangkan yang melakukan persalinan dengan cara sectio caesarea sebanyak 24 responden.

Berdasarkan tabel hasil penelitian dapat dilihat dari 30 responden, lebih dari separoh $(63,3 \%)$ memiliki pengetahuan kurang baik di bangsal Kebidanan RSU Mayjend H.A Thalib Sungai Penuh Tahun 2021. Penelitian Suryani (2012) dengan judul Pengetahuan dan Dukungan Suami terhadap Ibu Bersalin dengan Sectio Caesarea di RSUD. M. Zen Painan mengatakan bahwa pengetahuan berhubungan dengan tindakan serta keputusan yang diambil seseorang dengan hasil uji statistik alfa =0,037.

Section Caesarea adalah suatu persalinan buatan, dimana janin dilahirkan melaului suatu insisi pada 
dinding perut dan dinding rahim dengan syarat rahim dalam keadaan utuh serta berat janin diatas 500 gram (Wiknyosastro, 2005). Pengetahuan merupakan hasil tahu dan terjadi setelah orang melakukan penginderaan terhadap suatu obyek tertentu. Penginderaan terjadi melalui pancaindera manusia yakni: indra penglihatan, pendengaran, penciuman, rasa dan raba (Notoatmodjo, 2010). Berdasarkan analisa peneliti didapatkan bahwa sebagian besar responden memiliki pengetahuan yang kurang terhadap persalina secara sectio caesarea.

Berdasarkan asumsi peneliti, pengetahuan responden kurang baik $63,3 \%$ hal ini disebabkan karena rendahnya tingkat pendidikan responden dimana 53,3\% berpendidikan SD dan SLTP sedangkan yang berpendidikan sarjana 6,7 \%. Rendahnya tingkat pengetahuan juga disebabkan karena 100\% ibu bekerja sebagai ibu rumah tangga sehingga responden kurang terpapar informasi.

\section{Analisa Bivariat}

Hasil penelitian 24 orang responden yang mengalami kejadian sectio caesarea terdapat 15 orang $(78,9 \%)$ dengan pengetahuan kurang baik, dan 9 orang $(12,1 \%)$ bersalin mengalami kejadian sectio caesare memiliki pengetahuan baik pada ibu bersalin di bangsal Kebidanan RSU Mayjend H.A Thalib Sungai Penuh Tahun 2021. Hasil uji statistic menggunakan uji chi square didapatkan nilai $p=0,032 \quad(p<0,05)$ artinya tidak terdapat hubungan faktor pengetahuan dengan kejadian sectio caesarea di bangsal Kebidanan RSU Mayjend H.A Thalib Sungai Penuh Tahun 2021.

Penelitian ini tidak sejalan dengan penelitian yang dilakukan oleh
Yulia Puspita Sari (2011), telah melakukan penelitian sebelumnya di Puskesmas Krian Sidoarjo Jawa Timur, dengan hasil penelitian yaitu Hubungan Antara Tingkat Pengetahuan Persepsi Tentang Sectio Caesarea yang disebabkan oleh $104 \mathrm{ibu}$ dengan persentase (53,8\%) berpengetahuan kurang tentang Sectio Caesarea. Pengetahuan merupakan hasil tahu dan terjadi setelah orang melakukan penginderaan terhadap suatu obyek tertentu. Penginderaan terjadi melalui pancaindera manusia yakni: indra penglihatan, pendengaran, penciuman, rasa dan raba (Notoatmodjo, 2010).

Berdasarkan analisa peneliti didapatkan bahwa responden yang memiliki pengetahuan baik sebanyak $(36,7 \%)$ dan kurang baik $(63,3 \%)$ dan yang menjalani persalinan dengan sectio caesarea sebanyak $(37,5 \%)$ dengan pengetahuan baik, sedangkan responden yang memiliki pengetahuan kurang baik juga menjalani persalinan secara sectio caesarea sebanyak $(62,5 \%)$. Pada penelitian ini tidak ditemukan bahwa pengetahuan mempengaruhi persalinan secara sectio caesarea. Responden yang memiliki pengetahuan baik atau kurang baik tetap memilih melakukan persalinan secara sectio caesarea. Karena responden sangat percaya dengan diagnosis dari dokter yang menganjurkan bersalin dengan sectio caesarea. Serta di dukung oleh banyaknya ( 5 orang ) tenaga dokter spesialis obstetri ginekologi yang siap melayani 24 jam termasuk di hari libur.

Rendahnya tingkat pengetahuan responden disebabkan oleh rendahnya tingkat pendidikan, dimana lebih dari separuh (53\%) responden berpendidikan SD dan SLTP 
dan $100 \%$ responden hanya ibu rumah tangga (tidak bekerja) kemungkinan responden kurang terpapar dengan informasi sectio caesarea.

\section{KESIMPULAN}

Berdasarkan hasil penelitian dan pembahasan yang telah dilakukan maka dapat ditarik kesimpulan ada hubungan pengetahuan dengan kejadian sectio caesarea di Bangsal Kebidanan RSU Mayjend H.A Thalib Sungai Penuh Tahun 2021.

\section{DAFTAR PUSTAKA}

Azwar. (2009). Ilmu Kandungan Jilid 1. Jakarta :SalembaMedika

Bensons dan Parnoll. (2005). Pesalinan, Patologis Ibu Hamil. Jakarta : Medical

Bobak. (2005). Buku Ajar Keperawatan Maternitas. Jakarta : EGC

Daniyah. (2011). Faktor-faktor patologis yang berhubungan dengan kejadian sectio caesarea di RSUD Solo. Jakarta : ProfileBidanku.

Dinkes. (2015). Profil Kesehatan Kota Padang tahun 2015. Padang, Dinkes Padang.

DwiArma. (2011). Faktor-faktor yang Berhubungan dengan Kejadian Sectio Caesarea. Pendidikan Kesehatan Reproduksi.

Guyton \& Hall. (2007). Anatomi Fisiologis Kedokteran. Jakarta :Gramedia

Irfandi. (2011). Hubungan Pengetahuan Ibu dan Riwayat Bekas Sectio Caesarea dengan Sectio Caesare di RS. Ciputat. Jakarta : Bidanku

Kudus. (2003). Patologis Persalinan. Jakarta : EGC
Suryani. (2013). Hubungan Faktor Ketuban Pecah Dini dengan Kejadian Sectio Caesarea Pada Ibu Bersalin di RS.Premier : Jakarta Timur

Sarwono. (2013). Kehamilan, Persalinan, Kesehatan Ibu dan Anak. Jakarta : EGC

Manuaba,IBG. (2009).Ilmu Kebidanan Penyakit Kandungan Dan Keluarga Berencana. Jakarta:EGC.

Manuaba. (2009). Memahami Kesehatan Reproduksi Wanita. Jakarta: EGC

Mardianis. (2004). Kesehatan Resproduksi Wanita. Yogyakarta : Nuha Medika

Maryam. (2008). Ilmu Keperawatan Maternitas Vol 1. Jakarta : EGC

Mifatul. (2012). Faktor-faktor yang Mempengaruhi sectio caesarea pada ibu bersali di RSU Majalengka.

Mitayani. (2009). Asuhan Keperawatan Maternitas. Jakarta : Salemba Medika.

Nani, Rahayu. (2013). Faktor-faktor yang mempengaruhi wanita bersalin sectio caesarea di RSUD Zainal Abidin Banda Aceh.

Notoadmodjo, Soekidjo. (2010). Metode Penelitian Kesehatan. Jakarta :RinekaCipta

Prawirohardjo, S. (2009). Ilmu Kandungan. Jakarta: Yayasan Bina Pustaka Sarwono Prawirohardjo.

Registrasi Kebidanan RSUD. (2021). Rekamedik Bangsal Kebidanan RSU Mayjend H.A Thalib Sungai Penuh.

Riset Kesehatan Dasar. (2014). Badan Penelitian Dan Pengembangan Kesehatan Departemen Kesehatan. Jakarta: 
TAHUN [MANUJU: MALAHAYATI NURSING JOURNAL, ISSN CETAK: 2655-2728

2022 ISSN ONLINE: 2655-4712, VOLUME 4 NOMOR 2 FEBRUARI 2022] HAL 384-394

Departemen Kesehatan

Republik Indonesia

Syaiffudin. (2002). Ilmu Penyakit, Patologis dan Kesehatan. Jakarta : Graha Ilmu

Suharno \& Wahyu. (2013). Kesehatan Ibu dan Anak, Patofisiologis Kehamilan. Jakarta : Rineka Cipta

Veby Miyati, dkk. (2013). Anatomi Fisiologis Resproduksi dan Ilmu Kandungan. Jakarta : EGC

Wahyudi. (2008). Buku ajar Anatomi Fisiologi Keperawatan. Jakarta: NuhaMedika

Wahyudi. (2010). Prilaku dan Konsep Sehat jilid 1. Yogyakarta: Nuhamedika
Widyatul. (2009). Anatomi Fisiologis, Patologis Reproduksi jilid 2. Jakarta : Rineka Cipta.

Wiknyosastro. (2005). Anatomi Fisiologis Resproduksi dan Ilmu Kandungan. Jakarta : EGC

Sarim, Y. P. (2001). Hubungan Antara Tingkat Pengetahuan Persepsi Tentang Sectio Caesarea. 